DOI: https://doi.org/10.34069/AI/2021.45.09.16

How to Cite:

Zhura, S., \& Markin, V. (2021). Ways of improving tariff regulation efficiency. Amazonia Investiga, 10(45), 148-157. https://doi.org/10.34069/AI/2021.45.09.16

\title{
Ways of improving tariff regulation efficiency
}

\section{Пути повышения эффективности тарифного регулирования}

Received: June 27, 2021

\section{Abstract}

The system of tariff regulation in the Russian Federation has been experiencing improvements since the beginning of the transition period and up until today. The issues of tariff regulation are given particular attention to both in the Russian Federation and abroad. At the time, tariffs do not form subsequent to certain economic waves, but are in most cases described by an annual regulation cycle and a quite limited range of regulation with regard to the long-term horizon. The authors have analyzed average consumer prices (tariffs) for particular services along with producer price indices by types of economic activities and average annual producer prices for main energy resources in Russia over the last 20 years based upon the official statistical data. The authors conclude that it is necessary to introduce new ways of improving tariff regulation efficiency. Among the priority ways are the following: formation of an investment-worthy tariff and justification of the supporting tariff for crucial social projects; digital tariff modeling and etc. All these changes require methodological justification and further development of the variable supporting tariff theory in order to test new cyclic models of regulation matching the cyclic economy of the country.

Keywords: cyclic development, differential tariffs, tariffs, tariff modeling, tariff regulation.
Accepted: August 30, 2021

Written by: Svetlana Zhura ${ }^{62}$ https://orcid.org/0000-0001-5383-4971 Vladimir Markin ${ }^{63}$ https://orcid.org/0000-0002-7965-4968

\begin{abstract}
Абстрактный
Система тарифного регулирования в Российской Федерации совершенствуется с начала переходного периода и по настоящее время. Вопросам тарифного регулирования уделяется особое внимание как в Российской Федерации, так и за рубежом. В настоящее время тарифы не формируются после определенных экономических волн, но в большинстве случаев описываются годовым циклом регулирования и довольно ограниченным диапазоном регулирования в отношении долгосрочного горизонта. Авторы проанализировали средние потребительские цены (тарифы) на отдельные услуги, а также индексы цен производителей по видам экономической деятельности и среднегодовые цены производителей на основные энергоресурсы в России за последние 20 лет на основе официальных статистических данных. Авторы делают вывод о необходимости внедрения новых способов повышения эффективности тарифного регулирования. Среди приоритетных направлений: формирование инвестиционного тарифа и обоснование поддерживающего тарифа для важнейших социальных проектов; цифровое моделирование тарифов и т. д. Все эти изменения требуют методологического обоснования и дальнейшего развития теории поддерживающих переменных тарифов, чтобы протестировать новые циклические модели регулирования, соответствующие циклической экономике страны.
\end{abstract}

Ключевые слова: цикличность развития, дифференцированные тарифы, тарифы, тарифное моделирование, тарифное регулирование.

\footnotetext{
${ }^{62}$ Candidate of Economic Sciences, Associate Professor of the Northern (Arctic) Federal University named after M. V. Lomonosov, Arkhangelsk, Russia.

${ }^{63}$ Doctor of Economics, Chief Researcher Plekhanov Russian University of Economics, Moscow, Russia.
} 


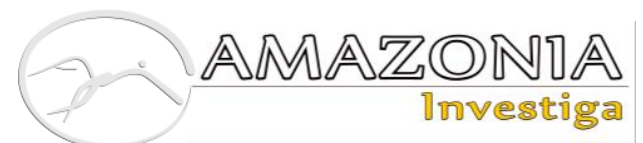

Introduction

Russian economy, just as other countries' economies, is currently going through a crisis due to the latest global events. Oil prices on global markets have been falling and there has been a diminution in demand. Surges, crunches, crises and revivals has been long considered regular phenomena both for regional and national economies. Crises go beyond certain economic sectors and affect groups of countries or even entire continents translating into global financial crises with grave social consequences. Apart from being shocked with the pandemic and quarantine restrictions in 2020, Russian economy faced severe slump in oil demand and contracted at $3.1 \%$ annualized rate as of the end of the same year, in accordance with the first estimations made by the Federal State Statistics Service (Starostina, 2021).

In economics, it is common to differentiate between the short-term cycles lasting from 3 to 4 years, middle-term cycles of 6 to 13 years and long-term cycles with a duration of 40 to 60 years. Regardless of the cycle length, there is always an issue relating to their overlapping and multiplicative properties. At the same time, it shall be noted that tariffs do not form subsequent to certain economic waves, but are in most cases described by an annual regulation cycle and a quite limited range of regulation with regard to the long-term horizon. The tariffs are basically defined by linear regulation as far as their growth rates are concerned. It is very common to substantiate such linear character with social significance and predictability.

One specific feature of tariff regulation typical for Russia is considerable dispersion of prices and tariffs, which is conditioned by either regional peculiarities in organization of power generation and public utility systems, by strong regulation, or by inefficiency of infrastructure providers.

It shall be noted that the role of the state in defining price dynamics in the infrastructure sector (partly subject to government regulation) is obviously not limited to mere determination of price and tariff change rates.

Since the beginning of the transition period and up until today, the tariff regulation system in the Russian Federation has been experiencing improvements. The recent years have introduced some changes, of which the following are worth mentioning: long-term approach to the definition of criteria applying to change of regulated tariffs at the macrolevel, increased share of liberalized markets (in the fields of electric power industry, gas and heat supply), development of methodological tools used for regulation, and availability of information on the activities carried out by both regulated and regulating organizations. In most of the cases, the abovementioned transformations correspond to the trends observed in foreign tariff regulation practices. Yet there are differences. For instance, foreign countries demonstrate more intense involvement of regulating authorities. Among particular focus areas, one can distinguish tariffbased stimulation of product line extension and service quality improvement at the regulated companies, including services in the fields of energy efficiency and energy conservation, as well as tariff-based stimulation of cutting-edge innovations in the infrastructure sector. With regard to implementation of such tasks, Russia currently falls behind, which is expressed in the Report on the analysis of key trends in the field of state tariff regulation prepared by the Institute for Economics and Regulation of Natural Monopolies with contributions from the Institute of Competition Policy and Market Regulation at the National Research University Higher School of Economics (2020).

\section{Literature Review}

The issues of tariff regulation are given particular attention to both in the Russian Federation and abroad, since the state regulates tariffs to protect the economic interests of consumers from monopolistic tariff increases in the first place, to ensure manufacturers' equal access to energy markets in the second place and to align the interests of electrical and heat energy producers and consumers in the third place.

This domain is ruled by statutory instruments most of which are aimed at tariff regulation in certain fields, e.g. in electric power industry, public utility services, transport, communication services, gas supply, etc.

In the recent years, there has been some relevant scientific research carried out on the issue of tariffs. Specifically, several authors study the most appropriate tariff structure, which could encourage a regulated utility company to promote energy efficiency among its customers. This research asserts that the most appropriate tariff structure also depends on the consumer's effort value and on the substitution degree of 
consumer's and company's efforts (Abrardi \& Cambini, 2015).

Much attention is paid to the issues of tariff differentiation. Following the market segmentation, it is possible to identify different consumer categories to offer them any necessary services ranging in dependence to various social and economic factors (Di Vittorio, 1996).

As far as transport area is concerned, researchers note that cargo vehicles freight rates vary for different goods carried along the same route, equally as rates per unit of distance vary for the same goods traveling different routes, which is accounted for by the competitive behavior (Beilock, Garrod \& Miklius, 1986). Researchers also look into the issues of tariff elasticity and level of service in the field of passenger carriage (White \& Turner, 1991). Research into the matters of transport cost reduction is aimed at the development of improved methods allowing to search for the least time tracks within the traffic system, including those along the international transport corridors, by applying analysis and modeling of freight transport along road networks (Prokudin, Oliskevych, Chupaylenko \& Maidanik, 2020).

Tariff study allows for rather important conclusions on interrelation between certain types of human activities. For instance, the analysis has shown that over the long term, the land rent decreases due to the increase in energy prices. Energy demand in the agricultural industry goes down if land and energy are renewable resources. Researchers throughly analyze all the factors influencing energy price formation and provide their arguments in favor of more efficient methods (Bhattacharyya, 1996). A lot of emphasis is put upon the issues of energy efficiency. National policies, especially those of the European Union, foster state and private programs stimulating involvement into the energy-efficiency-above-all strategies. Such policies result in moderate energy demand and serves as a durable solution protecting households from price fluctuations and energy poverty, while at the same time allowing the population to reduce their environmental impact and save their money for many years to come (Cornelis, 2020).

Scientists conduct their research into the main trends and directions of antimonopoly regulation, analyze natural monopolies and hypothesize efficient implementation of methods and tools of antimonopoly and tariff regulation in Russia (Knyazeva \& Svitych, 2015).
Individual authors regard state tariff regulation from the positions of efficiency and transparency of regulation mechanisms and potential unreasonable conduct of Russian regulating authorities (Kuznetsov, 2019). Of particular interest are the studies revealing the mechanisms, which ensure engagement of consumers into the energy demand management (Lenyucheva \& Matyunina, 2020).

There are many researchers who deal with the issues of tariff regulation efficiency in respect to certain areas, e.g. electric power industry (Mukhanova \& Yolokhova, 2018), public utility services (Gudzhel, 2019), water supply (Agafonov \& Kuznetsov, 2020), and others.

Some authors argue that the tariff setting model for the integrated use of traditional and alternative energy sources is based not only on the economic justification, but also on the dynamics of the use of alternative energy sources (Kapitonov \& Patapas, 2021). The authors also analyze the impact of the regulation of green tariffs on the retail electricity price for industrial consumers (Costa-Campi \& Trujillo-Baute, 2015). The authors investigate the impact of tariffs on waste management and conclude that optimizing the tariff structure reduces waste management costs (Di Foggia \& Beccarello, 2020).

Relevant are the studies that are conducted in various countries and regions. Each country has its own characteristics and experience in tariff regulation, which generally helps to develop common solutions to problems. For example, tariff regulation challenges are explored from the experience of Brazil (Sampaio \& Sampaio, 2020), tariff liberalization policy is explored through the example of Morocco (Ruckteschler, Malik \& Eibl, 2021), comparison of preferential tariffs and sold Green certificates is being investigated in the Spanish electric power system (Ciarreta, Paz Espinosa \& Pizarro-Irizar, 2017), the analysis of tariff policy is studied on the experience in Argentina (Samper, Coria \& Facchini, 2021).

\section{Methods}

Within the framework of research into tariff regulation and the ways of improving its efficiency, the authors resort to the range of economic analysis methods. The method of economic statistics is used as a set of methods necessary for comprehensive description of a phenomenon development by means of mass digital data. The following methods of statistical 


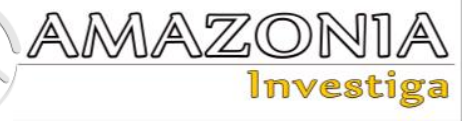

data processing and analysis were used to evaluate the information: economic grouping, absolute and relative values, economical comparison, etc.

The grouping method made it possible to divide the studied number of objects into qualitatively similar groups according to the required characteristics (by services, by types of resources, by types of economic activity). The analysis of the groups presented in the study was carried out using the method of absolute values. This method made it possible to evaluate quantitative phenomena and carry out their quantitative assessment. The use of the method of relative values made it possible to compare the studied groups with each other for a more accurate assessment of the indicators. These methods are the basis for using the method of economic comparison, on the basis of which conclusions are drawn about the trends in the development of processes related to the regulation of tariff activities. All the methods were used together and complemented each other in the research process.

In their study, the authors used official statistics from the Federal State Statistics Service to conduct the analysis for the period from 2010 to 2019. The use of official sources ensured the reliability of the indicators for the study. The researches had enough time to make an economic comparison in dynamics and draw more reliable conclusions about the phenomena occurring.

\section{Results}

The authors have analyzed the main parameters indicative of the tariff regulation in Russia (Federal State Statistics Service, 2020). Table 1 provides the analysis of average consumer prices (tariffs) for certain types of services over the last 20 years based upon the official statistical data.

Table 1.

Analysis of average consumer prices (tariffs) for certain services.

\begin{tabular}{|c|c|c|c|c|c|c|c|}
\hline \multirow[b]{2}{*}{ Services } & \multicolumn{5}{|c|}{ Roubles per one type of service } & \multicolumn{2}{|l|}{ Times } \\
\hline & 2000 & 2010 & 2017 & 2018 & 2019 & $\begin{array}{l}2019 \text { to } 2010 \\
\text { (increase/ } \\
\text { decrease) }\end{array}$ & $\begin{array}{l}2019 \text { to } 2000 \\
\text { (increase/ } \\
\text { decrease) }\end{array}$ \\
\hline City bus fare, per trip & 2.62 & 12.90 & 24.87 & 23.71 & 25.59 & 1.98 & 9.77 \\
\hline Tram fare, per trip & 2.70 & 13.01 & 26.14 & 26.67 & 29.67 & 2.28 & 10.99 \\
\hline Trolleybus fare, per trip & 2.58 & 12.36 & 23.94 & 26.02 & 28.61 & 2.31 & 11.09 \\
\hline Metro fare, per trip & 4.31 & 20.50 & 36.92 & 36.44 & 38.36 & 1.87 & 8.90 \\
\hline $\begin{array}{l}\text { Payment for housing in } \\
\text { the state } \\
\text { and municipal housing } \\
\text { stock, } \\
\text { per sq. m of total area }\end{array}$ & 1.30 & 14.28 & 28.87 & 31.10 & 30.48 & 2.13 & 23.45 \\
\hline $\begin{array}{l}\text { Cold water supply, per } \\
\text { cu. m }\end{array}$ & $\cdots$ & $\cdots$ & 26.64 & 28.08 & 29.47 & - & - \\
\hline Heating, per Gcal & $\ldots$ & $\ldots$ & 1771.19 & 1818.60 & 1895.33 & - & - \\
\hline $\begin{array}{l}\text { Gas (pipe line), monthly } \\
\text { per person }\end{array}$ & 5.66 & 43.81 & 73.04 & 75.59 & 77.94 & 1.78 & 13.77 \\
\hline $\begin{array}{l}\text { Electricity supply, } \\
\text { dwellings without } \\
\text { electric stove, for } \\
\text { minimum consumption, } \\
\text { per } 100 \mathrm{kWh}\end{array}$ & 39.16 & 232.03 & 371.44 & 387.16 & 400.64 & 1.73 & 10.23 \\
\hline Cinema ticket & 23.11 & 167.19 & 260.50 & 263.13 & 266.02 & 1.59 & 11.51 \\
\hline Theater ticket & 33.60 & 278.17 & 659.41 & 673.13 & 726.22 & 2.61 & 21.61 \\
\hline $\begin{array}{l}\text { Primary advising } \\
\text { appointment with a } \\
\text { medical } \\
\text { specialist }\end{array}$ & 62.97 & 341.30 & 683.90 & 724.61 & 780.86 & 2.29 & 12.40 \\
\hline
\end{tabular}


The analysis of average consumer prices (tariffs) for particular types of services allows for the conclusion that all services has become more expensive over the recent years. There has been a significant increase in prices for accommodation in state and municipal housing stock: in 2019, the prices were 23.45 times as high as those in 2000. With regard to the sphere of arts, theater tickets became 21.61 times more expensive over the same period. Pipeline gas prices increased thirteenfold and electrical energy became 10.23 times as expensive. Over the last 20 years, public transport fares have increased tenfold for virtually every means of transportation.

The authors have analyzed the producer price indices by types of economic activities (Table 2).

Table 2.

Producer price indices by economic activity

\begin{tabular}{|c|c|c|c|c|c|}
\hline \multirow{2}{*}{ economic activity } & \multicolumn{5}{|l|}{ percent } \\
\hline & 2014 & 2016 & 2017 & 2018 & 2019 \\
\hline $\begin{array}{l}\text { Production of } \\
\text { industrial articles }\end{array}$ & 106.1 & 104.3 & 107.6 & 111.9 & 102.9 \\
\hline $\begin{array}{l}\text { Mining and } \\
\text { quarrying }\end{array}$ & 106.7 & 100.3 & 115.2 & 125.1 & 103.2 \\
\hline $\begin{array}{l}\text { Mining of coal and } \\
\text { lignite }\end{array}$ & 99.6 & 115.0 & 136.5 & 106.9 & 95.6 \\
\hline $\begin{array}{l}\text { Extraction of } \\
\text { crude petroleum } \\
\text { and natural gas }\end{array}$ & 110.2 & 97.0 & 117.5 & 135.3 & 102.3 \\
\hline Manufacturing & 105.9 & 105.0 & 105.7 & 109.3 & 102.5 \\
\hline $\begin{array}{l}\text { Manufacture of } \\
\text { food products }\end{array}$ & 108.1 & 106.0 & 98.3 & 101.1 & 104.0 \\
\hline $\begin{array}{l}\text { Manufacture of } \\
\text { textiles }\end{array}$ & 103.9 & 107.0 & 101.3 & 102.3 & 104.0 \\
\hline $\begin{array}{l}\text { Manufacture of } \\
\text { wearing apparel }\end{array}$ & 102.9 & 105.6 & 102.2 & 102.5 & 103.4 \\
\hline $\begin{array}{l}\text { Manufacture of } \\
\text { basic } \\
\text { pharmaceutical } \\
\text { products and } \\
\text { pharmaceutical } \\
\text { preparations }\end{array}$ & 106.2 & 105.2 & 101.8 & 101.9 & 104.7 \\
\hline $\begin{array}{l}\text { Electricity, gas, } \\
\text { steam and air } \\
\text { conditioning } \\
\text { supply }\end{array}$ & 106.6 & 106.9 & 105.7 & 103.9 & 104.1 \\
\hline $\begin{array}{l}\text { Water supply; } \\
\text { sewerage, waste } \\
\text { management } \\
\text { and remediation } \\
\text { activities }\end{array}$ & $\cdots$ & $\ldots$ & 109.5 & 103.1 & 103.9 \\
\hline
\end{tabular}

Analysis of the producer price indices by types of economic activities allows to assert an average increase in production of industrial articles by $2.9 \%$ in 2019. There has been a rise in prices for virtually all types of commodities: prices for manufacture of basic pharmaceutical products and pharmaceutical preparations increased by 4.7\%; prices for electricity, gas, steam and air conditioning supply went up by $4.1 \%$; manufacture of food products and textiles became $4 \%$ more expensive; mining and quarrying prices grew by more than $3 \%$; prices in manufacturing sector and in the field of extraction of crude petroleum and natural gas increased by more than $2 \%$. It shall be noted, however, that the highest increase in producer prices by types of economic activities took place in 2018 (by an average of 11.9\%) and in 2017 (by an average of $7.6 \%$ ). The increase can be attributed to such systematic factors as weakening of the ruble against the background of falling oil prices and capital outflow.

The authors have analyzed average annual producer prices for main energy resources (Table 3). 
Table 3.

Analysis of average annual producer prices for main energy resources

\begin{tabular}{|c|c|c|c|c|c|c|c|}
\hline \multirow[b]{2}{*}{$\begin{array}{l}\text { energy } \\
\text { resources }\end{array}$} & \multicolumn{4}{|c|}{ Average prices, Roubles } & \multicolumn{3}{|l|}{ Times } \\
\hline & 2010 & 2017 & 2018 & 2019 & $\begin{array}{l}2018 \text { to } 2017 \\
\text { (increase, } \\
\text { decrease) }\end{array}$ & $\begin{array}{l}2019 \text { to } 2018 \\
\text { (increase, } \\
\text { decrease) }\end{array}$ & $\begin{array}{l}2019 \text { to } 2010 \\
\text { (increase, } \\
\text { decrease) }\end{array}$ \\
\hline $\begin{array}{l}\text { Coking coal, per } \\
\text { tonne }\end{array}$ & 1262 & 4073 & 4518 & 4121 & 1.11 & 0.91 & 3.27 \\
\hline $\begin{array}{l}\text { Coal, excluding } \\
\text { anthracite, } \\
\text { coking coal and } \\
\text { lignite, per } \\
\text { tonne }\end{array}$ & 718 & 1543 & 1815 & 1717 & 1.18 & 0.95 & 2.39 \\
\hline $\begin{array}{l}\text { Crude oil, per } \\
\text { tonne }\end{array}$ & 6631 & 14698 & 21186 & 21430 & 1.44 & 1.01 & 3.23 \\
\hline $\begin{array}{l}\text { Natural gas, per } \\
\text { thou. cu. } m\end{array}$ & 605 & 1950 & 1721 & 1912 & 0.88 & 1.11 & 3.16 \\
\hline $\begin{array}{l}\text { Motor gasoline, } \\
\text { per tonne }\end{array}$ & 15961 & 25251 & 29598 & 25152 & 1.17 & 0.85 & 1.58 \\
\hline $\begin{array}{l}\text { Diesel fuel, per } \\
\text { tonne }\end{array}$ & 13330 & 25469 & 33405 & 31649 & 1.31 & 0.95 & 2.37 \\
\hline $\begin{array}{l}\text { Heavy fuel oil, } \\
\text { per tonne }\end{array}$ & 7478 & 8483 & 12864 & 13137 & 1.52 & 1.02 & 1.76 \\
\hline $\begin{array}{l}\text { Electricity, per } \\
\text { thou. } \mathrm{kWh}\end{array}$ & 647 & 998 & 1040 & 1063 & 1.04 & 1.02 & 1.64 \\
\hline
\end{tabular}

Analysis of the average annual producer prices for main energy resources has revealed an increase in prices for heavy fuel oil (by 52\%), crude oil (by 44\%) and diesel fuel (by 31\%) in 2018 as opposed to 2017. At the same time, the price for natural gas went down (by $12 \%$ ). Not as many energy resources demonstrated price increase in 2019 as compared to 2018. In particular, natural gas price went up by $11 \%$, which is explained by the fact that this resource did not go up in price in 2018, as noted above. That said, prices for motor gasoline, coking coal, diesel fuel/coal decreased by $15 \%, 9 \%$ and $5 \%$, respectively, which might be attributed to the slowdown in global economic growth caused by the global financial crisis. Generally speaking, there has been an increase in prices for all energy resources over the last ten years. The prices for coking coal and natural gas experienced a significant rise by more than three times, whereas diesel fuel became more than two times as expensive.

As previously noted, the analysis conducted has shown the tariff increase rates over the last twenty years. There has also been an increase in average consumer prices (tariffs), producer price indices by types of economic activities and average annual producer prices for main types of energy resources.

In Russia, tariff calculations provide for the establishment of the latter at a level, which would ensure the projected revenue from rendering services in the field of regulated activities in favor of the regulating authority in the amount necessary to cover their reasonable expenses. The tariff structure shall also include taxes and other mandatory payments in accordance with the Russian Federation legislation. For instance, heat energy tariff rates are to a considerable extent affected by the expenses associated with the type of fuel (liquid and solid fuels are more expensive than natural gas), heating plants efficiency, as well as the way the heat energy is generated (if heat energy is generated by making use of the combined method, i.e. by power stations working in the mode of simultaneous heat (power) and electricity generation, the prime cost of such heat energy is much lower, which also influences the tariff rate). Differences in prices of services rendered by organizations conducting activities in the field of water supply and disposal are conditioned by the scope of such services, location of water supply and disposal facilities, spread and wear degree of water supply and disposal networks, technological characteristics of water treatment facilities and other factors.

Annual revision of tariffs for public utilities in connection with changing external conditions ensures seamless operation of utility companies along with quality and availability of public utility services for consumers.

The Government of the Russian Federation approved plans to increase the following tariffs 
for the public: electricity tariff by $5 \%$ from July 2021, gas tariff by $3 \%$ from July 2021, and passenger rail fares by $3.7 \%$ from January 2021. According to the Ministry of Economic Development, increase of tariffs for heat supply, water supply and water disposal, as well as ultimate indices of changes in payments made by the population for utility services in the period from 2021 to 2023, will remain at the level set forth in September 2019 by the Forecast of Social and Economic Development of the Russian Federation up to 2024 with a focus on the inflation rate (Finmarket Information Agency, 2020).

The authors, however, are convinced that minimum linear growth within the ultimate index from year to year cannot be considered an appropriate strategy capable of respecting the interests of all market stakeholders, and not only consumers - especially those being the citizens (population) - which requires resorting to the new ways of improving tariff regulation efficiency.

\section{Discussion}

It is the authors' opinion that priority ways of improving the tariff regulation efficiency are as follows:

1. Formation of an investment-worthy tariff and justification of the supporting tariff for crucial social projects

Efficiency in the perception of investments at various stages of an investment project is described in a number of academic papers. However, there are only few references to the efficiency of investments along the entire project life cycle. Interrelation between varying life cycle efficiency and tariff regulation also remains an underdeveloped area. It is obvious that tariff guides all parties to the investment process and aligns the interests of different stakeholders in such a way as to achieve the maximum efficiency of a particular service over the long term. Yet this is only possible with due regard to the entire project life cycle in conformity with tariff flexibility at different stages.

Tariff regulation in the investment process can either function as an accelerator of both direct and indirect project investments, or stimulate application of investments towards the most desirable areas, e.g. recovery of engineering infrastructure displaying excessive wear.
The authors are convinced that tariff regulation is able to foster investment raising and application of investments towards the essential focus areas. Tariff regulation can control the process of a service prime cost optimization, while improving the overall service efficiency. However, investment appeal starts with respecting the investor's interests with regard to repayment predictability and risk mitigation. In this scenario, tariff does not only define the return on investment in the project and its payback period, but it is also a key driver in a systematic approach to the rehabilitation of a certain industry. If that is the case, such tariff may be defined as a supporting tariff.

\section{Development of digital tariff strategies}

In the near future, Federal Antimonopoly Service of Russia (FAS) is planning to strengthen the role of its Unified Information and Analytical System by enhancing it with an intellectual digital platform allowing to implement integration of data on prices and tariffs, including those in the field of electric power industry. At the time, it is planned to introduce a so-called Digital Tariff Signal Light, a system designed to control the decision-making process with regard to tariffs. This mechanism will send a clear signal to the regulating authorities as to compliance of their decisions with legal requirements. Implementation of this tool would allow to compare the expenses incurred by the regulated organizations with the reference values, and to monitor the decisions of the regional regulating authorities before they are made. In the long term, integration of macroeconomic data will provide for implementation of a whole number of other digital tools.

\section{Digital tariff modeling}

In order to identify the priorities of the investment process to stabilize the prime cost within the tariff structure, it is necessary to be able to carry out digital modeling of tariff consequences. Such digital models make it easy to examine several scenarios underpinning the calculations for the most appropriate tariff strategy. It is necessary to develop a methodological strategy and mathematical tools to substantiate tariff efficiency at a particular stage of the cycle. It is also essential to determine the planning horizon with respect to the project cycle, and to develop guidelines on mitigation of negative consequences for all market stakeholders. Big data analysis is extremely important to be able to differentiate between the existing approaches to tariffs setting in 


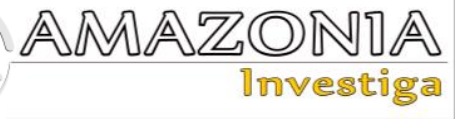

dependence to the socioeconomic conditions in the region.

4. Elaboration of tariff structure and regulations applicable to the tariff formation process

Tariff is the only element of traditional marketing ensuring company's real income. Market tariff is not an independent variable, since its value depends on the values of other marketing elements, as well as on the level of competition in the market and on the general state of economy.

The main purpose of tariff formation strategy for the market economy is gaining maximum profit while maintaining the sales targets. The tariff strategy has to ensure persistent satisfaction of customers' needs by means of reasonable combination of internal development strategy at the company and external parameters within a single long-term marketing strategy. Hence, tariff strategy development requires each particular enterprise to define the main objectives thereof, e.g. maximizing revenue, tariff, sales, or competitiveness, while securing fixed return on investment.

5. Introduction of differential tariffs when regulating consumption of socially important resources

Differential tariffs are used across a wide range of fields: customs, public utility services, logistics, and service sector. Differential tariff is also extensively used in the energy supply market. Depending on the region, as well as on the price of services, electricity tariffs vary across the country. Planned increases in price take place annually, yet price discrimination permits flat owners to save substantial amounts. Being aware of how the multirate system works, people choose the appropriate meter and pay less for the rendered services starting from the following month.

There are two main stakeholders in this issue: suppliers and consumers of electricity. The benefits of multirate system might be obvious for individuals, yet there are subtleties when it comes to producers. For instance, peak electricity demand periods make it more lucrative for the suppliers to set higher prices for their services. During the night, when most customers rest and do not use any electrical power, the tariff will decrease. Such calculation principle is explained by the achievement of desirable values in production and consumption of electrical energy.
It is beneficial for suppliers to entice customers into consuming their resources at certain times.

For instance, hot and cold water supply tariffs can be set on a differential basis when the following parameters are taken into account:

a) availability of several technologically unrelated centralized cold (hot) water supply systems;

b) volumes of water consumption;

c) conformity of drinking and hot water quality with the requirements set forth in sanitary rules and regulations.

The essence of this system lies in applying differential tariffs to one resource, which might be used in other sectors.

\section{Conclusion}

Thus, it can be said that cycle-like nature of economic processes predetermines the necessity of flexible (non-linear) tariff regulation fully corresponding to the market expectations and ensuring maximum efficiency of both budgetary and extra-budgetary investments. Investment appeal of the tariff becomes one of the main tasks on the way of renovation and major overhaul of a certain industry. Investment appeal of the tariff lies in the long-term tariff regulation, which is at least comparable to the project investment cycle. Contemporary economic development underpinned by generating big amounts of data and their further management is impossible without digitalization followed by digital modeling and development of digital strategies. Alongside this, real-time monitoring of both the strategy and tariff efficiency seems indispensable.

All these changes require methodological justification and further development of the variable supporting tariff theory in order to test new cyclic models of regulation matching the cyclic economy of the country.

\section{Bibliographic references}

Abrardi, L. \& Cambini, C. (2015). Tariff regulation with energy efficiency goals. Energy Economics, 49(C), 122-131.

Agafonov, D. V. \& Kuznetsov, V. V. (2020). Specific features of introducing reference price formation to Russian water supply companies with regard to international practices of tariff regulation. Bulletin of the Moscow University named after S.Yu. Witte. Edition 1, Economics and management, 
2(33), 64-72. https://vestnikmuiv.ru/article/osobennosti-vnedreniyaetalonnogo-tsenoobrazovaniya-v-otnosheniirossiyskikh-predpriyatiy-vodosnabzh/

Beilock, R., Garrod, P. \& Miklius, W. (1986). Freight charge variations in truck transport markets: price discrimination or competitive pricing? American Journal of Agricultural Economics, 68(2), 226-236.

Bhattacharyya, S. C. (1996). Domestic energy pricing policies in developing countries: why are economic prescriptions shelved? Energy Sources, 18(8), 855-874.

Ciarreta, A., Paz, Espinosa, M., Pizarro-Irizar, C. (2017). Optimal regulation of renewable energy: A comparison of Feed-in Tariffs and Tradable Green Certificates in the Spanish electricity system. Energy Economics, 67, 387-399. https://doi.org/10.1016/j.eneco.2017.08.028

Cornelis, M. (2020). Energy efficiency, the overlooked climate emergency solution. Economic policy, 15(2), 48-67.

Costa-Campi, M.T., \& Trujillo-Baute, E. (2015). Retail price effects of feed-in tariff regulation. Energy Economics, 51, 157-165. https://doi.org/10.1016/j.eneco.2015.06.002

Di Foggia, G., \& Beccarello, M. (2020). The impact of a gain-sharing cost-reflective tariff on waste management cost under incentive regulation: The Italian case. Journal of environmental management, 265. https://doi.org/10.1016/j.jenvman.2020.1105 26

Di Vittorio, A. (1996). Identifying, measuring and responding to different market segments: price determination in air transport. Journal of Vacation Marketing, 2(4), 315-325.

Federal State Statistics Service. (2020). Bank of Ready-to-Use Documents. Russia in numbers - 2020. Retrieved from https://www.gks.ru/bgd/regl/b20_11/Main.ht m (date of access: May 08, 2021).

Finmarket Information Agency. (2020). The increase in tariffs in 2021 for electricity for the population will be $5 \%$, for gas - $3 \%$, for railway transportation $-3.7 \%$. Retrieved from http://www.finmarket.ru/news/5321110 (date of access: May 8, 2021).

Gudzhel, I. A. (2019). International practices of tariff regulation in the field of rail transportation. Bulletin of the Faculty of Management of the Saint Petersburg State University of Economics, 6, 33-37.

Kapitonov, I.A., \& Patapas, A. (2021). Principles regulation of electricity tariffs for the integrated generation of traditional and alternative energy sources. Renewable and
Sustainable Energy Reviews, 146. https://doi.org/10.1016/j.rser.2021.111183

Knyazeva, I. V. \& Svitych, N. Yu. (2015). System of indicators used to determine the efficiency of state regulation of natural monopolies and gas market._Siberian School of Finance, 6(113), 19-26.

Kuznetsov, V. A. (2019). Tariff regulation: in need of a standardized approach. In: I. V. Fedoseev (Ed.), Theory and practice of managing state functions and services. Tariff regulation. Collected papers in follow-up of the $2^{\text {nd }}$ National Research and Practice Conference (pp. 111-115). St. Petersburg: St. Petersburg State University of Economics.

Lenyucheva, A. D. \& Matyunina, Yu. V. (2020). Engagement of consumers into the energy demand management. In: I. G. Akhmetova, N. V. Rozhentsova, V. R. Ivanova (Ed.), Challenges and prospects in the development of electrical energy industry and electrical engineering. Proceedings of the $2^{\text {nd }}$ National Research and Practice Conference, Vol. 1 (pp. 209-2014). Kazan: Kazan State Energy University.

Mukhanova, D. Yu. \& Yolokhova, I. V. (2018). Estimation of efficiency of investment projects implemented by electricity distribution companies in electrical energy industry against the background of tariff regulation. Bulletin of the Perm National Research Polytechnic University. Social and economic sciences, 4, 183-196.

National Research University Higher School of Economics. (2020). Tariff policy in the Russian Federation in the industries of the communal sphere: priorities, problems, perspective. HSE report. Moscow: Higher School of Economics Publishing House.

Prokudin, G., Oliskevych, M., Chupaylenko, O. \& Maidanik, K. (2020). Optimization model of freight transportation on the routes of international transport corridors. Journal of Sustainable Development of Transport and Logistics, 5(1), 66-76.

Ruckteschler, C., Malik, A., \& Eibl, F. (2021). Politics of trade protection in an autocracy: Evidence from an EU tariff liberalization in Morocco. European Journal of Political Economy,

69. https://doi.org/10.1016/j.ejpoleco.2021.1020 63

Sampaio, P.R.P., \& Sampaio, R.S.R. (2020). The challenges of regulating water and sanitation tariffs under a three-level shared-authority federalism model: The case of Brazil. Utilities Policy, 64. https://doi.org/10.1016/j.jup.2020.101049 
Samper, M., Coria, G., \& Facchini, M. (2021). Grid parity analysis of distributed PV generation considering tariff policies in Argentina. Energy Policy, 157. https://doi.org/10.1016/j.enpol.2021.112519

Starostina, Yu. (2021). Russian economy is going through the gravest economic slump in 11 years. Economics: RosBiznesConsulting.
Retrieved

from https://www.rbc.ru/economics/01/02/2021/6 017e1819a7947cb98f23f95 (date of access: May 08, 2021).

White, P. \& Turner, R. (1991). Overall impacts of local bus deregulation in Britain. Transportation Planning and Technology, 15(2-4), 203-229. 